Bull. Chem. Soc. Ethiop. 2012, 26(2), 181-193.

Printed in Ethiopia

ISSN 1011-3924

DOI: http://dx.doi.org/10.4314/bcse.v26i2.3

(C) 2012 Chemical Society of Ethiopia

\title{
KINETIC AND EQUILIBRIUM STUDY FOR THE SORPTION OF Pb(II) IONS FROM AQUEOUS PHASE BY WATER HYACINTH (Eichhornia crassipes)
}

\author{
Genson Murithi, Charles. O. Onindo ${ }^{*}$ and Gerald. K. Muthakia \\ Department of Chemistry, Kenyatta University, P.O. Box 43844, Nairobi, Kenya
}

(Received November 10, 2010; revised December 26, 2011)

\begin{abstract}
This paper reports the kinetic and equilibrium studies of Eichhornia crassipes root biomass as a biosorbent for $\mathrm{Pb}$ (II) ions from aqueous system. Batch adsorption studies were carried out to examine the influence of various parameters such as the $\mathrm{pH}$, contact time, adsorbent dose, initial metal ion concentration, temperature and agitation speed on the metal ion uptake. Uptake of $\mathrm{Pb}$ (II) ions on the E. crassipes roots showed a $\mathrm{pH}$-dependent profile. The maximum metal uptake values were $164 \mu \mathrm{g} / \mathrm{mL}$. Langmuir model fitted the experimental sorption equilibrium data with a good fit $\left(\mathrm{R}^{2}>0.99\right)$. The biosorption kinetics was described by the pseudo-second-order model $\left(\mathrm{R}^{2}>0.99\right)$.
\end{abstract}

KEY WORDS: Water hyacinth, Biosorption, Kinetics, Water treatment, $\mathrm{Pb}(\mathrm{II})$ removal

\section{INTRODUCTION}

Presence of heavy metals in aquatic systems has become a serious problem. More attention is now given in the search of new technologies for the removal of heavy metals from contaminated waters. Conventional technologies used to remove heavy metals from wastewater or aqueous systems such as precipitation, ion exchange; ultra filtration, reverse osmosis and electrodialysis have certain disadvantages. Most often there is incomplete metal ion removal, high reagent and energy consumptions. This has made it imperative to search for other cost effective and more efficient treatment methods that are capable of removing heavy metals from contaminated waters $[1,2]$.

The new technologies currently being investigated involve the use of biosorption, which is a passive process for adsorption of the metal ions by metabolically inactive biomass. It is dependent on the affinity between the metal species or its ionic forms, anionic and other forms of contaminants and the binding sites on the molecular structure of the cell wall. Biosorption utilizes natural dead materials such as agricultural wastes and by-products like sawdust, rice husk, spent grain, bark of trees, modified corncobs among others. These are inexpensive, efficient and often naturally occurring biodegradable products [3].

Biological treatment of wastewaters to recover heavy metals is a growing field in both industrialized and developing countries. Compared to physical-chemical techniques that are costly, less efficient and may lead to secondary pollution problems, biological systems are more appealing. In fact the adsorbents prepared from agricultural wastes were claimed to be nearly five times cheaper than the commercial activated carbon [2].

The widespread industrial use of low-cost adsorbents for wastewater treatment is strongly recommended at present, due to their local availability, technical feasibility, engineering applicability and cost effectiveness. Therefore the search for efficient and low cost biosorbent has increased. Most of these are agriculture wastes or by-products, which are considered to be low value products. Different types of biomass have been investigated for their capacity to remove heavy metals from aqueous solutions with a considerable degree of success [4-11].

Eichhornia crassipes plant has also recently received attention because of its potential for removal of pollutants when utilized as a biological filtration system. A number of phyto-

*Corresponding author. E-mail: coonindo@yahoo.com 
remediation studies have been carried out $[12,13]$. However, use of this method takes a lot of time as it is inefficient when dealing with large volume of industrial waste water. Furthermore, live plants when used are cumbersome.

The present work reports the kinetic and equilibrium studies of the $\mathrm{Pb}$ (II) ions binding to raw biomass of $E$. crassipes. This would provide a source of relatively cheap, economically and environmentally friendly water filters for heavy metal ions removal in aqueous systems. Currently E. crassipes is considered undesirable species on inland waterways. The biosorption process has been analyzed through batch experiments with regard to the influence of the initial metal ion concentration, adsorbent dose, temperature, $\mathrm{pH}$, the presence of other metal ions, contact time and shaking speed.

\section{EXPERIMENTAL}

\section{Biomass}

The samples of water hyacinth (E. crassipes) were obtained from Nairobi Dam, which is in Nairobi city, Kenya. They were subsequently identified and classified by a botanist. The pH of the dam water was also measured on site. Upon arrival in the laboratory the E. crassipes samples were washed with $0.1 \mathrm{M}$ nitric acid and rinsed several times with deionised water until a $\mathrm{pH}$ of around 5.0 to 6.5 ( $\mathrm{pH}$ of the dam water) was obtained. The E. crassipes root biomass was then dried in an oven at $60{ }^{\circ} \mathrm{C}$ for $24 \mathrm{~h}$ after which they were crushed and sieved (size fraction of $0.5-1 \mathrm{~mm}$ ) and stored in polythene bottles until ready for use.

\section{Apparatus}

Atomic absorption spectrophotometer (AAS) (Buck, model 210 VGP) was used for analysis of $\mathrm{Pb}$ (II) ions. The AAS was set at the optimum operating conditions at wavelength $283.3 \mathrm{~nm}$; the slit length was maintained at $0.7 \mathrm{~nm}$ with the detection limit of $0.002 \mu \mathrm{g} / \mathrm{mL}$. All the $\mathrm{pH}$ measurements were performed with a calibrated (Jenway 3505) pH-meter equipped with a standard calomel electrode (SCE). Polarographic analyzer/Stripping voltammeter model 303 A was used for the analysis of $\mathrm{Pb}$ (II) ions. Constant shaker model C.F.C. 3018 was used in agitating the samples at the required speeds while the centrifuge model Centurion 6000 series was used for separating the residue from the solution. A water bath model SB3D was used for temperature regulation.

\section{Reagents}

All chemicals used were of analytical grade unless otherwise stated. $\mathrm{Pb}$ (II) standard stock solution of $1000 \mu \mathrm{g} / \mathrm{mL}$ was prepared from the nitrate salt (Merck) in distilled water. All working standards were subsequently prepared from this stock solution.

\section{Determination of the equilibrium time}

$0.1000 \mathrm{~g}$ of biomass was mixed with $100 \mathrm{~mL}$ solutions of $\mathrm{Pb}(\mathrm{II})$ ions at initial concentrations of 10,50 and $100 \mu \mathrm{g} / \mathrm{mL}$. The mixture was shaken constantly at a speed of $200 \mathrm{rpm}$. Aliquots were withdrawn at predetermined time intervals within a period of $1.5 \mathrm{~h}$. The solutions were centrifuged at a speed $3800 \mathrm{rpm}$ for $20 \mathrm{~min}$ and $\mathrm{Pb}$ (II) ion concentration in the supernatant measured by AAS. 
Effect of the shaking speed

An adsorbent dose of $0.1000 \mathrm{~g}$ was placed in a $250 \mathrm{~mL}$ conical flask containing $100 \mathrm{~mL}$ of 10 $\mu \mathrm{g} / \mathrm{mL} \mathrm{Pb}$ (II) ions and agitated for $20 \mathrm{~min}$ at various speeds between $0 \mathrm{rpm}$ and $200 \mathrm{rpm}$. Thereafter the samples were centrifuged and the supernatant analysed for the remaining $\mathrm{Pb}(\mathrm{II})$ ions.

\section{Effect of adsorbent dose}

The effect of varying adsorbent mass while maintaining the concentration constant was studied as follows: $0.10,0.20,0.30,0.40,0.50$ and $0.60 \mathrm{~g}$ portions of the adsorbent was placed in 100 $\mathrm{mL}$ of $10 \mu \mathrm{g} / \mathrm{mL} \mathrm{Pb}$ (II) ions. After $150 \mathrm{~min}, 10 \mathrm{~mL}$ aliquots were withdrawn, centrifuged and the supernatant was analyzed for the remaining $\mathrm{Pb}(\mathrm{II})$ ions.

\section{Effect of temperature}

Batch experiments were carried out using $0.1000 \mathrm{~g}$ E. crassipies added to $100 \mathrm{~mL}$ of $10 \mu \mathrm{g} / \mathrm{mL}$ at equilibrium $\mathrm{pH}$ of 5.0 at the following temperatures: $15,25,35,45$ and $55 \pm 1{ }^{\circ} \mathrm{C}$. The adsorption mixture was agitated for $150 \mathrm{~min}$ and the remaining solution was analyzed for $\mathrm{Pb}$ (II) ions at each temperature.

\section{Effect of $p H$}

$0.1000 \mathrm{~g}$ E. crassipes biomass, weighed accurately was added to $100 \mathrm{~mL}$ of $10 \mu \mathrm{g} / \mathrm{mL}$ solutions of $\mathrm{Pb}$ (II) ions maintained at $25 \pm 1{ }^{\circ} \mathrm{C}$ and at $\mathrm{pH} 3.0,4.0,5.0,6.0$ or 7.0. The $\mathrm{pH}$ was varied from 1.0 to 7.0 by careful addition of $0.1 \mathrm{M}$ nitric acid or $0.1 \mathrm{M}$ sodium hydroxide drop wise until the desired $\mathrm{pH}$ was obtained. The mixtures were agitated for approximately $150 \mathrm{~min}$, centrifuged and the concentrations of $\mathrm{Pb}$ (II) ions in equilibrium with the solid E. crassipes $\left(\mathrm{C}_{\mathrm{eq}}\right)$ determined. The recovery value was calculated at each $\mathrm{pH}$ value. The procedure was repeated for 50 and $100 \mu \mathrm{g} / \mathrm{mL} \mathrm{Pb}$ (II) ion concentrations.

\section{Effect of the initial metal ion concentrations}

While keeping the amount of adsorbent constant in a $100 \mathrm{~mL}$ solution, the initial metals ion concentrations were varied from 10 to $300 \mu \mathrm{g} / \mathrm{mL}$. The mixtures, usually in triplicate were shaken at a speed of $175 \mathrm{rpm}$ for about $150 \mathrm{~min}$ at a temperature of $25 \pm 1{ }^{\circ} \mathrm{C}$. The mixtures were then filtered and the filtrate was analyzed for the remaining metal ion concentration using AAS. The average values were used to calculate the amount and the percentage of metal ions adsorbed from each initial metal ion concentrations.

\section{Adsorption kinetics}

The rate of adsorptions of $\mathrm{Pb}$ (II) ions by $E$. crassipes was studied as follows: $0.1000 \mathrm{~g}$ of the adsorbent was mixed with $100 \mathrm{~mL}$ of $10 \mu \mathrm{g} / \mathrm{mL} \mathrm{Pb}$ (II) ions maintained at $25 \pm 1{ }^{\circ} \mathrm{C}$ and $\mathrm{pH}$ of 5.0 in a $200 \mathrm{~mL}$ plastic bottle closed tightly with a lid. Shaken at $175 \mathrm{rpm}, 5 \mathrm{~mL}$ aliquots were withdrawn at predetermined time intervals using syringe fitted with a membrane filter and the solution was analyzed using $\mathrm{AAS}$ for the remaining $\mathrm{Pb}$ (II) ions.

\section{Adsorption isotherms}

$100 \mathrm{~mL}$ of $\mathrm{Pb}$ (II) ions solution of concentrations ranging from 10 to $600 \mu \mathrm{g} / \mathrm{mL}$ were placed in $100 \mathrm{~mL}$ Erlenmeyer flasks containing $0.1000 \mathrm{~g}$ of the root biomass. The mixtures were placed in 
a rotary shaker for $150 \mathrm{~min}$ at a temperature of $25 \pm 1{ }^{\circ} \mathrm{C}$, and then filtered through a $0.45 \mu \mathrm{m}$ pore size cellulose nitrate membrane filter and the filtrate was analyzed for the remaining metal ion concentration.

\section{Effect of other metal ions on the adsorption of $\mathrm{Pb}(\mathrm{II})$}

$50 \mathrm{~mL}$ of $20 \mu \mathrm{g} / \mathrm{mL} \mathrm{Na}, \mathrm{K}, \mathrm{Ca}$ or $\mathrm{Mg}$ ions and optimized mass of E. crassipes biomass were added simultaneously to a flask containing $50 \mathrm{~mL}$ of $20 \mu \mathrm{g} / \mathrm{mL} \mathrm{Pb}$ (II) solution at optimum conditions and shaken for $150 \mathrm{~min}$. One flask containing $\mathrm{Pb}$ (II) ions and optimized mass of $E$. crassipes at the same conditions was used as a control (without the competing metal ions). The mixtures were then centrifuged and the resulting solution after decantation was analyzed for $\mathrm{Pb}(\mathrm{II})$ ions using AAS. All experiments were done in triplicate.

\section{RESULTS AND DISCUSSION}

\section{Kinetics studies}

\section{Effect of contact time}

Figure 1 shows the variation in the amounts of $\mathrm{Pb}(\mathrm{II})$ ions adsorbed with contact time at the initial metal ion concentrations of 10,50 and $100 \mu \mathrm{g} / \mathrm{mL}$.

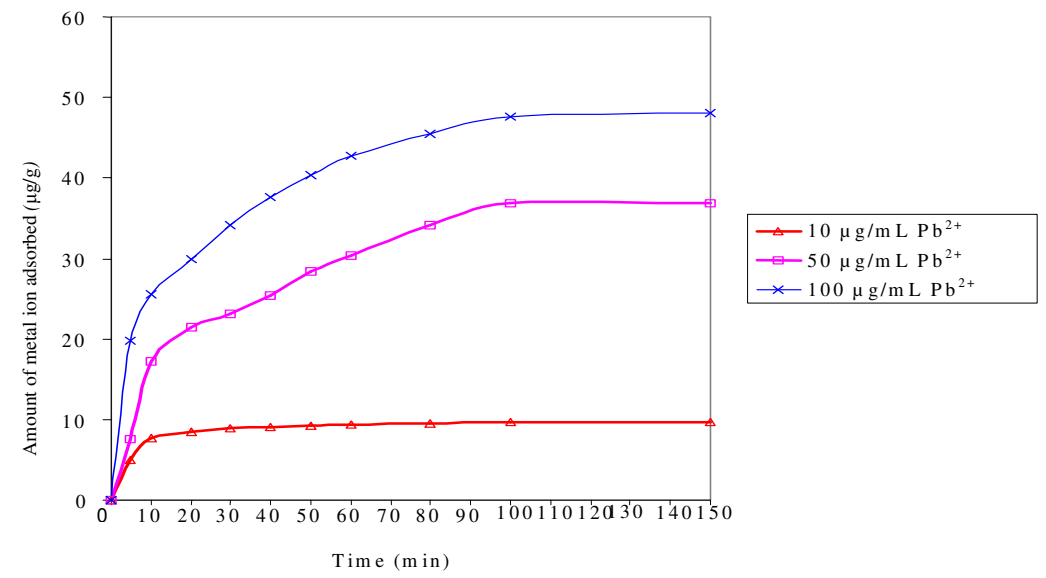

Figure 1. Effect of contact time on the adsorption of $\mathrm{Pb}$ (II) ions by E. crassipes at $\mathrm{pH} 5.0$, agitation speed $175 \mathrm{rpm}$, temperature $25 \pm 1{ }^{\circ} \mathrm{C}$.

The results show that the percentage of metal ions adsorbed by E. crassipes increased with increasing time of equilibration and reached a plateau value at about $100 \mathrm{~min}$. Biosorption of $\mathrm{Pb}$ (II) ions by E. crassipes could be divided into two stages, a first initial stage followed by a much slower biosorption stage. Similar results have been reported [1, 7, 14]. The first initial metal biosorption rate is attributed to the surface binding by natural particles, followed by a slower sorption to the interior. Different kinds of functional groups, with different affinities to the metal ions, are usually present at the biomass particles surface. The sites with similar affinities are firstly occupied and 100 min was sufficient for sorption to attain equilibrium. 


\section{Effect of shaking speed}

Figure 2 shows the effect of varying the agitation speed for adsorption of $\mathrm{Pb}$ (II) ions. The results show that the amount of metal ions adsorbed increased with the increase in the agitation speed. The maximum amount adsorbed occurred at $175 \mathrm{rpm}$, which, was taken as the optimized shaking speed and used in all the experiments. Ghodbane et al. [9] suggested that when increasing the agitation speed, the diffusion rate of metal ions from the bulk liquid to the liquid boundary layer surrounding sorbent particles become higher because of an enhancement of turbulence and a decrease of the thickness of the liquid boundary layer. Good diffusion of ions towards the sorbent particles is also ensured. Low et al. [15] suggested that increasing the agitation rate increases the external film mass transfer coefficient hence the rate of uptake. This is due to reduction of the film boundary layer surrounding the sorbent particles. According to Mckay [16] in a system where the agitation of solid in a solution is vigorous, intraparticle diffusion is likely to be the limiting step.

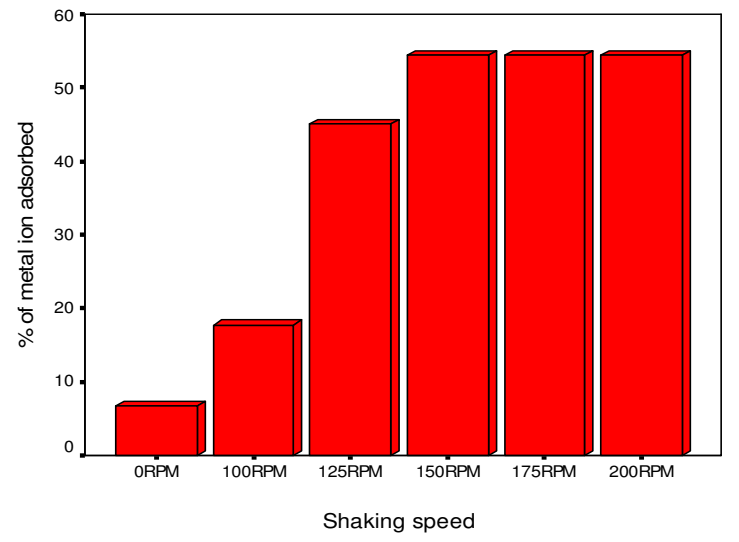

Figure 2. Effect of shaking speed on the adsorption of $\mathrm{Pb}(\mathrm{II})$ ions by $E$. crassipes. Initial ion concentration $10 \mu \mathrm{g} / \mathrm{mL}, \mathrm{pH} 5.0$, temperature $25 \pm 1{ }^{\circ} \mathrm{C}$, time $150 \mathrm{~min}$.

\section{Effect of sorbent dose}

The effect of a variation of sorbent mass on biosorption of $\mathrm{Pb}$ (II) ions on E. crassipes is reported in Figure 3. There was an increase in the percentage adsorption of $\mathrm{Pb}$ (II) from 87 to $93 \%$ when the adsorbent dose was increased from 100 to $200 \mathrm{mg} / 100 \mathrm{~mL}$ at the initial adsorbate concentration of $10 \mu \mathrm{g} / \mathrm{mL}$. The percentage adsorption thereafter slightly decreased. The results, therefore, suggest that the adsorption of $\mathrm{Pb}$ (II) ions increased with increase in sorbent dosage. This could be because at higher dose of adsorbent more adsorption sites are available due to increased surface area. Higher metal ions uptake at lower dry mass concentrations has also been attributed to an increased metal to biosorbent ratio, which decreases upon an increase in dry mass concentration [17]. At higher biomass to solute concentration ratios, there is a very fast superficial adsorption onto the sorbent surface that produces a lower solute concentration in the solution than when the biomaterial to solute concentration ratio is lower. This is because a fixed mass of biomass can only adsorb a certain amount of the metal ion [18].

The decrease in amount of $\mathrm{Pb}$ (II) ions adsorbed with increasing sorbent mass is due to the split in the concentration gradient between solute concentration in the solution and the solute concentration in the surface of the sorbent. Fourest et al. [19] observed that increased biomass 
concentration led to insufficiency of metal ions in solution with respect to binding metal ions. Thus with the increasing sorbent mass, the amount of $\mathrm{Pb}$ (II) ions sorbed onto unit weight of sorbent gets reduced causing a decrease in adsorption capacity with increasing sorbent mass concentration. Adsorbent dose of $0.1000 \mathrm{~g}$ was taken as the optimal adsorbent dose and used for all the experiments.

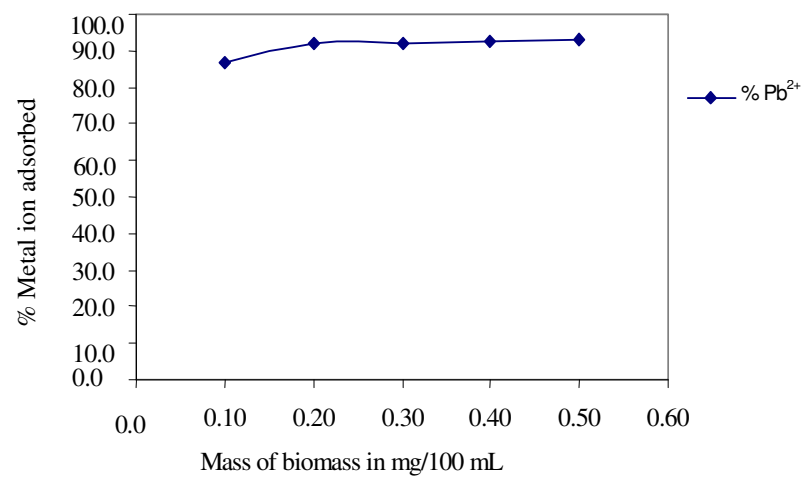

Figure 3. Effect of adsorbent dose on the biosorption of $\mathrm{Pb}(\mathrm{II})$ ions. Initial ion concentration 10 $\left(\mu \mathrm{g} / \mathrm{mL}, \mathrm{pH} 5.0\right.$, temperature $25 \pm 1^{\circ} \mathrm{C}$, time $150 \mathrm{~min}$, agitation speed $175 \mathrm{rpm}$.

\section{Effect of temperature}

The temperature of the adsorption medium could be important for energy dependent mechanisms in metal binding process. Figure 4 shows the variation of the sorbed amount versus temperature.

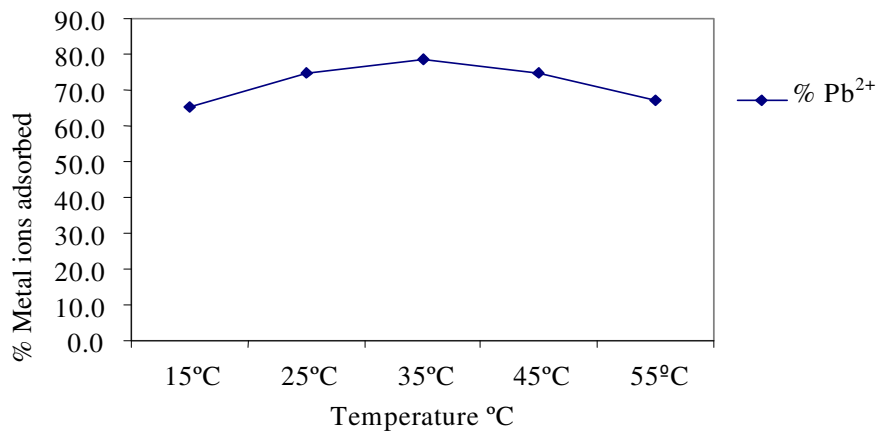

Figure 4. Effect of temperature on the biosorption of $\mathrm{Pb}$ (II) ions. Initial ion concentration 10 $(\mu \mathrm{g} / \mathrm{mL}), \mathrm{pH} 5.0$, adsorbent dose $0.1000 \mathrm{~g} / 100 \mathrm{~mL}$, time $150 \mathrm{~min}$, agitation speed 175 rpm.

Increasing the temperature from 15 to $55 \pm 1{ }^{\circ} \mathrm{C}$ led to an increase and then a decline in the amount of metal ions adsorbed. The percentage amount of $\mathrm{Pb}(\mathrm{II})$ ions adsorbed increased from 65 to $79 \%$ when the temperature was increased from 15 to $35 \pm 1{ }^{\circ} \mathrm{C}$. However, the adsorption decreased for temperature above $45{ }^{\circ} \mathrm{C}$. These results were similar with the findings of Lodeiro et al. [20] who observed that increasing the temperature favored the biosorption of $\mathrm{Pb}$ (II) ions on marine macroalga Cystoseira baccata. Benhima et al. [6] obtained similar results when they studied the adsorption of $\mathrm{Pb}(\mathrm{II})$ ions onto micro-particles of dry plants.

Bull. Chem. Soc. Ethiop. 2012, 26(2) 
Tokimoto et al. [21] noted that the amount of $\mathrm{Pb}(\mathrm{II})$ ions adsorbed on coffee grounds increased slightly when the temperature was varied between 278 and $298 \mathrm{~K}$. They suggested that the adsorbents whose adsorption capacities change little with temperature could be desirable. These results seem to indicate that a high temperature works against the removal of $\mathrm{Pb}$ (II) ions. The increase in temperature could cause deterioration of the matrix structure of the biomass, and then, it may probably result to loss of sorption sites, hence reducing the percentage of $\mathrm{Pb}(\mathrm{II})$ ions removal.

\section{Adsorption kinetics}

The $\mathrm{Pb}$ (II) ions adsorption data was modelled by the pseudo-second order kinetics equation 1 $[6,20,22,23]$.

$$
\frac{t}{q_{t}}=\frac{1}{K^{\prime} q_{e}^{2}}+\frac{t}{q_{e}}
$$

where $K^{\prime}$ is the pseudo-second order rate constant of adsorption, $q_{e}$ is the metal adsorbed at equilibrium ( $\mathrm{g} / \mu \mathrm{g} \mathrm{min}$ ), $t$ is the time taken for the adsorption to take place and $q_{t}$ is the metal adsorbed at a given time ( $\mu \mathrm{g} / \mathrm{g})$ [22]. Figures 5, 6 and 7 show the fittings obtained when 10, 50 and $100(\mu \mathrm{g} / \mathrm{mL})$ of $\mathrm{Pb}(\mathrm{II})$ ions were used respectively. In all the cases straight lines were obtained with regression of $0.9947,0.9795$ and 0.9949 , respectively

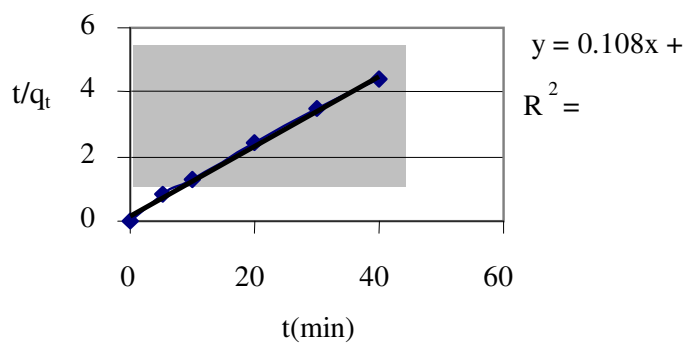

Figure 5. Fit of Pseudo-second order equation for the biosorption of $\mathrm{Pb}(\mathrm{II})$ ions. Initial ion concentration $10(\mu \mathrm{g} / \mathrm{mL}), \mathrm{pH} 5.0$, adsorbent dose $0.1000 \mathrm{~g} / 100 \mathrm{~mL}$, time $150 \mathrm{~min}$, agitation speed $175 \mathrm{rpm}$.

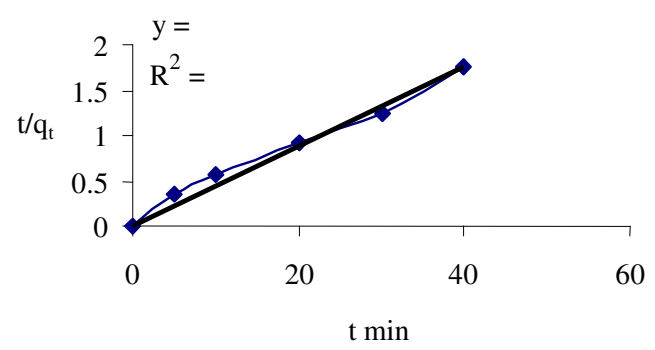

Figure 6. Fit of Pseudo- $2^{\text {nd }}$ order-equation for the biosorption of $\mathrm{Pb}$ (II) ions. Initial ion concentration $50(\mu \mathrm{g} / \mathrm{mL}), \mathrm{pH} 5.0$, adsorbent dose $0.1000 \mathrm{~g} / 100 \mathrm{~mL}$, time $150 \mathrm{~min}$, agitation speed $175 \mathrm{rpm}$. 


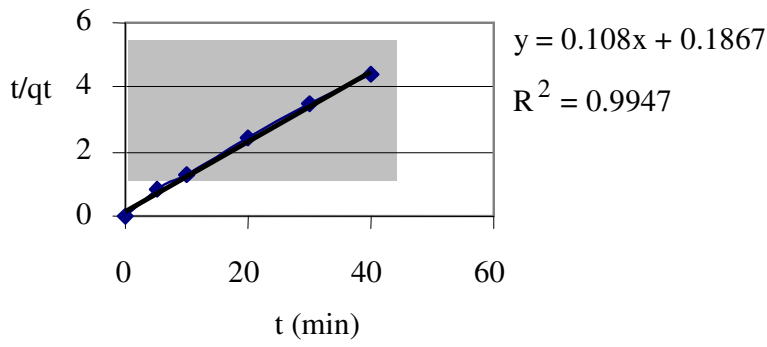

Figure 7. Fit of Pseudo- $2^{\text {nd }}$ order-equation for the biosorption of $\mathrm{Pb}(\mathrm{II})$ ions. Initial ion concentration $100(\mu \mathrm{g} / \mathrm{mL}), \mathrm{pH} 5.0$, adsorbent dose $0.1000 \mathrm{~g} / 100 \mathrm{~mL}$, time $150 \mathrm{~min}$, agitation speed $175 \mathrm{rpm}$.

From a plot of $\mathrm{t} / \mathrm{q}_{\mathrm{t}}$ against $\mathrm{t}$, Figure 7 , the pseudo-second order rate constant $\mathrm{K}$ ' of $\mathrm{Pb}$ (II) ions biosorption was found to be $0.3634 \mathrm{~g} / \mu \mathrm{g}$ min The model considers metal-biosorbent reaction as a rate limiting step. In this case, metal diffusion both in the bulk solution and in the biosorbent is considered faster than the reaction that takes place in the active binding sites [24].

Equilibrium studies

Effect of $p H$

The effect of $\mathrm{pH}$ on the adsorption of $\mathrm{Pb}$ (II) ions by E. crassipes is presented in Figure 8 . The maximum amount of $\mathrm{Pb}(\mathrm{II})$ ions adsorbed at the initial concentrations of 10,50 and $100 \mu \mathrm{g} / \mathrm{mL}$ were $8.13 \pm 0.15 \mu \mathrm{g} / \mathrm{g}$ (about $81 \%$ ), 21.67 $\pm 0.44 \mu \mathrm{g} / \mathrm{g}$ (about $43 \%$ ) and $28.65 \pm 0.29 \mu \mathrm{g} / \mathrm{g}$ (about $28 \%$ ), respectively at the $\mathrm{pH}$ of about 5 . Above $\mathrm{pH} 5.5$ insoluble lead hydroxide starts to form and therefore true adsorption study was impossible. The minimum amount of adsorbed $\mathrm{Pb}$ (II) ions occurred at $\mathrm{pH} 3.0$; this is because at low $\mathrm{pH}$ the biomass surface is completely covered by $\mathrm{H}^{+}$increasing the competition for the available adsorption sites with $\mathrm{Pb}(\mathrm{II})$ ions.

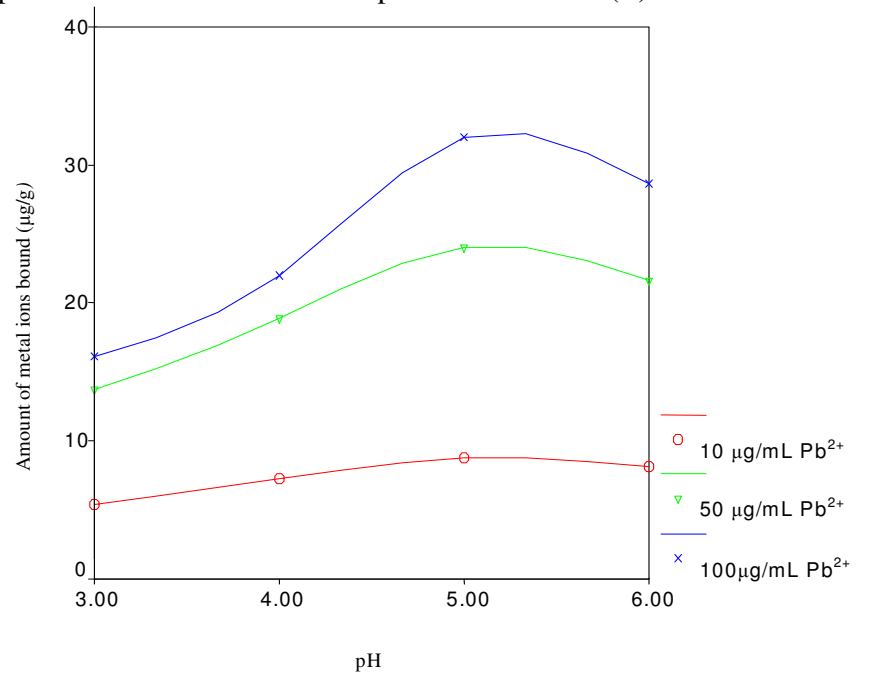

Figure 8. Effect of $\mathrm{pH}$ on the adsorption of $\mathrm{Pb}(\mathrm{II})$ ions by E. crassipies. Initial ion concentration $10(\mu \mathrm{g} / \mathrm{mL})$, adsorbent dose $100 \mathrm{mg} / 100 \mathrm{~mL}$, time $150 \mathrm{~min}$, agitation speed $175 \mathrm{rpm}$.

Bull. Chem. Soc. Ethiop. 2012, 26(2) 
Matheickal et al. [25] also got similar results when they studied the biosorption of $\mathrm{Pb}$ (II) ions from aqueous solutions by marine alga Ecklonia radiata. They also made similar observations when they studied the biosorption of $\mathrm{Pb}$ (II) and $\mathrm{Cu}$ (II) ions by Durnillaea Potatorum. Baig et al. [26] who studied the adsorption of heavy metal ions by the biomass Solanum elaegnifolium noted that as the $\mathrm{pH}$ of the solution increased from 2.0 to 6.0 the binding capacity of $\mathrm{Cd}(\mathrm{II}), \mathrm{Cr}(\mathrm{III}), \mathrm{Cu}(\mathrm{II}), \mathrm{Ni}(\mathrm{II}), \mathrm{Pb}$ (II) and $\mathrm{Sn}$ (II) ions increased with optimum binding occurring between 4.0 and 5.0. Gupta et al. [27] suggested that at low pH the biomass surface would be completely covered with $\mathrm{H}^{+}$and $\mathrm{Pb}$ (II) ions cannot complete with them for adsorption sites. This could be partly due to the fact that protons are strong competing sorbate because of their higher concentration. This could probably explain the low $\mathrm{Pb}$ (II) ions uptake at low $\mathrm{pH}$ effects of initial metal ion concentrations.

\section{The effect of initial metal ion concentrations and biosorption isotherms}

The effect of initial metal ion concentrations on the adsorption of $\mathrm{Pb}(\mathrm{II})$ ions by $E$. crassipies is presented in Table 1. From Table 1, initial ion concentrations have a significant effect on the uptake efficiency of the biomass. The highest percentage adsorption of $\mathrm{Pb}$ (II) ions occurred at concentration of $10 \mu \mathrm{g} / \mathrm{mL}$. About $81 \%$ of the initial concentration of lead was adsorbed. However, the highest adsorbed amount of about $24 \%$ was obtained for initial concentration of $300 \mu \mathrm{g} / \mathrm{mL}$ of $\mathrm{Pb}(\mathrm{II}))$ ions. As the initial concentration increased from 10 to $300 \mu \mathrm{g} / \mathrm{mL}$, there was an increase in the amount of the metal ions bound but the percentage quantity adsorbed decreased. E. crassipies therefore, has the highest adsorption capacity occurring at low concentrations of $\mathrm{Pb}$ (II) ions. The increase in the amount of metal ions adsorbed with increase in concentration has been attributed to large number of binding sites present on the adsorbent. The metal ions uptake also tends to saturate as the initial concentration is increased.

Table 1. Effect of initial metal ion concentrations on the adsorption of $\mathrm{Pb}(\mathrm{II})$ ions by E. crassipies. Initial ion concentration $10(\mu \mathrm{g} / \mathrm{mL}), \mathrm{pH} 5.0$, adsorbent dose $100 \mathrm{mg} / 100 \mathrm{~mL}$, time $150 \mathrm{~min}$, agitation speed $175 \mathrm{rpm}$.

\begin{tabular}{|c|c|c|}
\hline $\begin{array}{c}\text { Initial concentration } \\
{[\mathrm{Pb}(\mathrm{II}) \text { ions }](\mu \mathrm{g} / \mathrm{mL})}\end{array}$ & $\begin{array}{c}\text { Mean amount of } \mathrm{Pb}(\mathrm{II}) \text { ions adsorbed } \\
\pm \mathrm{sd}(\mu \mathrm{g} / \mathrm{g})\end{array}$ & $\begin{array}{c}\text { Percent adsorption of } \mathrm{Pb} \text { (II) ions, } \\
\%\end{array}$ \\
\hline 10 & $8.18 \pm 0.00$ & 81.67 \\
\hline 25 & $19.69 \pm 0.20$ & 78.78 \\
\hline 50 & $22.13 \pm 0.10$ & 44.25 \\
\hline 100 & $30.46 \pm 0.10$ & 30.46 \\
\hline 200 & $30.18 \pm 0.69$ & 15.09 \\
\hline 300 & $61.71 \pm 0.30$ & 20.57 \\
\hline
\end{tabular}

sd: standard deviation.

This can be explained by a progressive increase in electrostatic mutual interaction between sites that have lower affinity for metal ions as the population of occupied sites increases [28, 29]. A similar trend has been observed in removal of divalent metal ions, $\mathrm{Cu}$ (II), $\mathrm{Cd}$ (II), $\mathrm{Zn}$ (II) and $\mathrm{Pb}(\mathrm{II})$ by other biosorbents such as $P$. Labata (Ohwi Kudzu), E. speciosa, (Nile rose), $C$. semperirens (Cypress), E. longifolia (Cinchona) and P. haleperisis [30-33].

\section{Biosorption isotherms}

The biosorption data for $\mathrm{Pb}(\mathrm{II})$ ions was fitted into Langmuir adsorption isotherm equation 2 $[20,23]$. 


$$
q_{e}=\frac{b Q_{\max } C e q}{1+b C_{e q}}
$$

where $q_{e}$ corresponds to the amount of the metal ion adsorbed per gram of the adsorbent at equilibrium $(\mu \mathrm{g} / \mathrm{mL}), C_{e q}$ is the solute concentration $(\mu \mathrm{g} / \mathrm{mL})$ in aqueous solution after equilibrium was reached, $Q_{\max }$ represents practical limitation adsorption capacity when the surface is fully covered with metal ions and assists in the comparison of performance particularly in cases where the biosorbent did not reach its full saturation in the experiments. $b$ is an affinity constant for binding sites. It was also fitted in and Freundlich adsorption isotherm equation $3[22,27]$.

$$
\mathrm{q}_{\mathrm{e}}=\mathrm{K}_{\mathrm{f}} \mathrm{C}_{\mathrm{e}}^{\frac{1}{\mathrm{n}}}
$$

where $\mathrm{K}_{\mathrm{f}}$ and $n$ are Freundlich constants representing adsorption capacity and intensity, respectively. $n$ varies with the heterogeneity of the adsorbent.The biosorption data for $\mathrm{Pb}$ (II) ions was fitted into linearised Langmuir (equation 3) and Freundlich (equation 5) equations. The results that were obtained are indicated in Figures 9 and 10 and Table 2. The calculated Freundlich and Langmuir parameters were then compared to the same constants for various biosorbents as shown in Table 3.

Table 2. Freundlich and Langmuir parameters for $\mathrm{Pb}(\mathrm{II})$ ions adsorption on E. crassipes.

\begin{tabular}{|c|c|c|c|}
\hline \multicolumn{2}{|c|}{ Freundlich constants } & \multicolumn{2}{c|}{ Langmuir constants } \\
\hline$K_{f}(\mu \mathrm{g} / \mathrm{g})$ & 5.4038 & $Q_{\max }(\mu \mathrm{g} / \mathrm{g})$ & 163.9 \\
\hline $1 / \mathrm{n}$ & 0.6252 & $\mathrm{~b}$ & 0.0234 \\
\hline $\mathrm{r}^{2}$ & 0.8088 & $\mathrm{r}^{2}$ & 0.9887 \\
\hline
\end{tabular}

Table 3. Comparisons of the Freundlich and Langmuir parameters of various biosorbents for $\mathrm{Pb}$ (II) ions recovery.

\begin{tabular}{|l|c|c|c|c|c|c|}
\hline Biomass & Metal ion used & $K_{f}(\mu \mathrm{g} / \mathrm{g})$ & $1 / \mathrm{n}$ & $Q_{\max }(\mu \mathrm{g} / \mathrm{g})$ & $\mathrm{b}$ & Ref. \\
\hline Pomegranate peel & $\mathrm{Pb}(\mathrm{II})$ & 2.931 & 0.510 & 13.870 & 0.218 & {$[34]$} \\
\hline Peat & $\mathrm{Pb}(\mathrm{II})$ & 8.51 & 0.410 & 27.8 & 0.437 & {$[35]$} \\
\hline Kaolinite & $\mathrm{Pb}(\mathrm{II})$ & 24.71 & -0.2030 & 0.9770 & 0.4760 & {$[36]$} \\
\hline Smectite & $\mathrm{Pb}(\mathrm{II})$ & 0.4900 & 0.8480 & 3.1370 & 0.8170 & {$[36]$} \\
\hline Sugar beet pulp SBP & $\mathrm{Pb}(\mathrm{II})$ & 5.6 & 1.00 & 373.7 & 0.0986 & {$[8]$} \\
\hline
\end{tabular}

The $r^{2}$ values for Freundulich and Langmuir isotherms fit on the biosorption for $\mathrm{Pb}(\mathrm{II})$ ions were 0.8088 and 0.9887 as indicated in Table 2. On the basis of $r^{2}$, the Langmuir isotherm has a value close to 1 and hence fits better to the experimental data obtained than the Freundlich. The biosorption of $\mathrm{Pb}(\mathrm{II})$ ions on the E. crassipes is therefore mostly monolayer. Similar results were obtained by Panda et al. [11] and Oliveira et al. [5]. The value for b (affinity for the metal ions) for adsorption of $\mathrm{Pb}$ (II) ions on the biomass was found to be 0.0234. Regarding Freundlich isotherm, the slope $1 / \mathrm{n}$ ranging between 0 and 1 is a measure of adsorption intensity or surface heterogeneity. An average value of 0.63695 was observed for $1 / \mathrm{n}$ supports the fact that, adsorption takes place homogenously on the surface [5, 37]. 


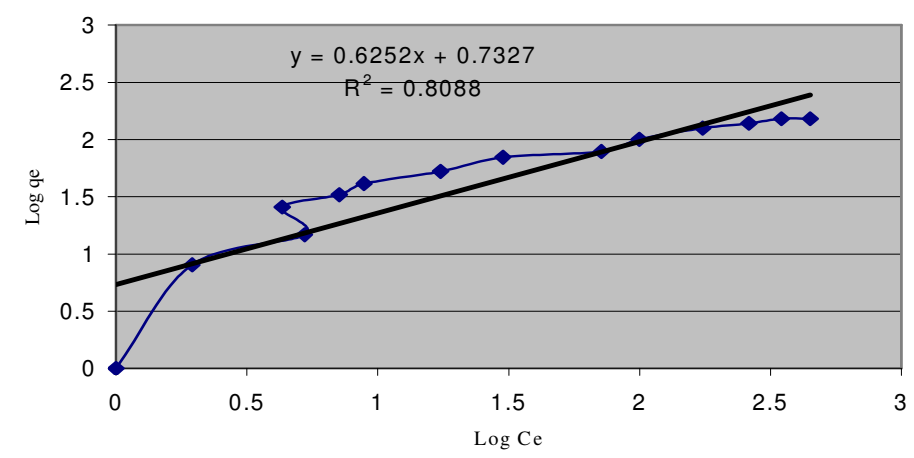

Figure 9. Freundlich biosorption isotherm for $\mathrm{Pb}(\mathrm{II})$ ions. Initial ion concentration $10(\mu \mathrm{g} / \mathrm{mL})$, pH 5.0, adsorbent dose $100 \mathrm{mg} / 100 \mathrm{~mL}$, time $150 \mathrm{~min}$, agitation speed $175 \mathrm{rpm}$.

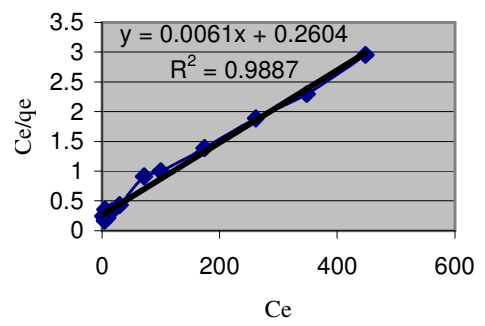

Figure 10. Langmuir biosorption isotherm for $\mathrm{Pb}$ (II) ions. Initial ion concentration $10(\mu \mathrm{g} / \mathrm{mL})$, $\mathrm{pH}$ 5.0, adsorbent dose $100 \mathrm{mg} / 100 \mathrm{~mL}$, time $150 \mathrm{~min}$, agitation speed $175 \mathrm{rpm}$.

\section{Effect of other metal ions on the biosorption of $\mathrm{Pb}(\mathrm{II})$ ions}

The effect of $\mathrm{Na}^{+}, \mathrm{K}^{+}, \mathrm{Mg}^{2+}$ and $\mathrm{Ca}^{2+}$ ions on the adsorption of $\mathrm{Pb}$ (II) ions by $E$. crassipes was studied and the results are shown in Figure 11. The results indicated that in the presence of these ions, the sorptive capacity of E. crassipes was decreased. The percentage reduction on the biosorption of $\mathrm{Pb}$ (II) ions when $\mathrm{Na}^{+}$and $\mathrm{K}^{+}$were used was 8.43 and $5.37 \%$, respectively. When $0.5 \mathrm{mM}$ was used the percentage reduction was 4.72 and $5.24 \%$ for the two metals. This indicated that the effect of $\mathrm{Na}^{+}$and $\mathrm{K}^{+}$on the biosorption was almost negligible. However the percentage reduction values were high, over $50 \%$ when $\mathrm{Ca}^{2+}$ and $\mathrm{Mg}^{2+}$ ions were used. Even though same moles were not used for this work, from calculation it was shown that a similar pattern may be expected. If $0.5 \mathrm{mM}$ was used, for example, then the expected percentage reduction may be 4.72 and $5.24 \%$ when $\mathrm{Na}^{+}$and $\mathrm{K}^{+}$were used. $\mathrm{Ca}^{2+}$ and $\mathrm{Mg}^{2+}$ may be 35 and $59 \%$, respectively. From the results, the singly charged ions have very little impact on the biosorption of the metal ions. The reduced binding capacity may be as a result of competition for binding sites and or by the increased concentration of metal ions in solution, which reduces mobility of the ions in solution. 


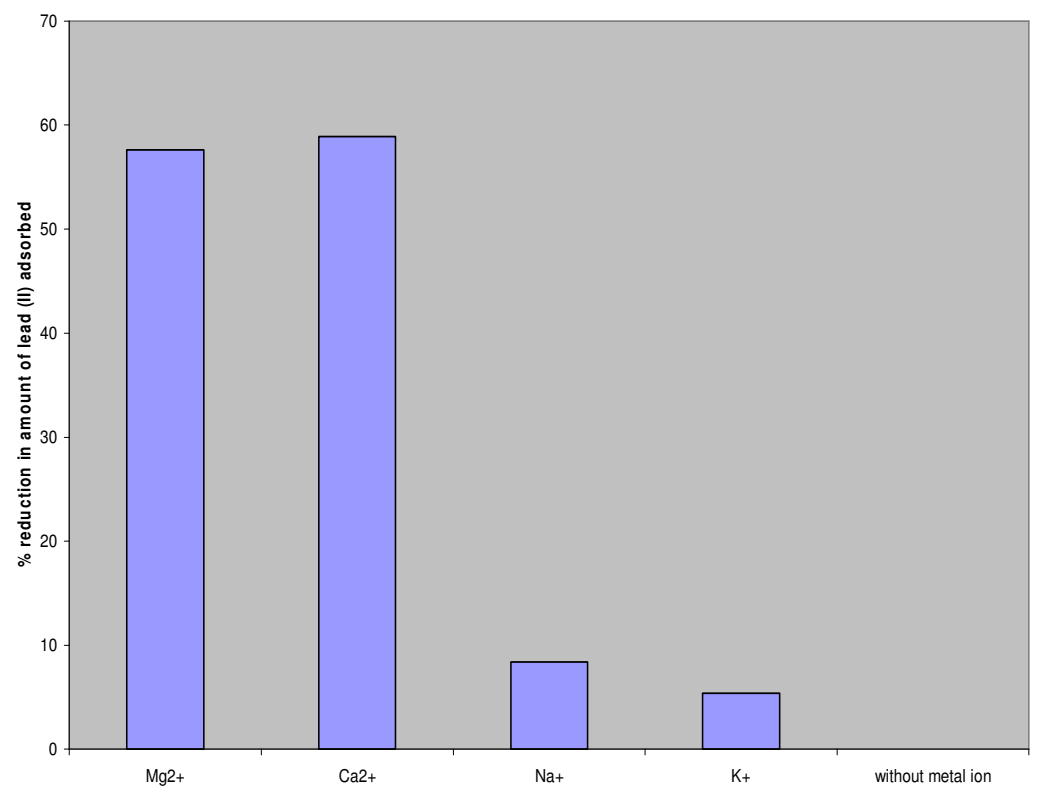

Figure 11. Effect of selected metal ions on the biosorption of $\mathrm{Pb}$ (II) ions. $\mathrm{pH} 5.0$, adsorbent dose $100 \mathrm{mg} / 100 \mathrm{~mL}$, time $150 \mathrm{~min}$, agitation speed $175 \mathrm{rpm}$.

\section{CONCLUSIONS}

The results of this work indicate that the water hyacinth (Eichhornia crassipes) constitutes a promising material for the development of a low cost biosorption technology for the removal of $\mathrm{Pb}$ (II) ions from water effluents. Metal sorption was fast and depended on contact time, initial metal ion concentration, sorbent dose, solution $\mathrm{pH}$, temperature and agitation speed. The adsorption data for E. crassipies fitted the Langmuir model for $\mathrm{Pb}$ (II) ions. The maximum sorption capacity was $164 \mu \mathrm{g} / \mathrm{g}$ at $25 \pm 1{ }^{\circ} \mathrm{C}$. A pseudo-second order model described the kinetic data. The maximum adsorption for $\mathrm{Pb}$ (II) ions occurred at a $\mathrm{pH}$ of 5.0.

\section{ACKNOWLEDGEMENTS}

We would like to express our sincere thanks to the Nairobi Dam staff for helping us to retrieve the water hyacinth from the dam and Mr G.P. Maina, the botanist who identified the samples.

\section{REFERENCES}

1. Vieira, H.S.F.; Volesky, B. Int. Microbial. 2000, 3, 17.

2. Villar, V.J.P.; Botelho, C.M.S.; Boaventura, R.A.R. Chem. Eng. J. 2008, 138, 249.

3. Kratochvil, D.; Volesky, B. Water Res. 1998, 32, 2760.

4. Singh, V.; Tiwari, S.; Sharma, A.K.; Sanghi, R. J. Colloid Interf. Sci. 2007, 316, 224.

5. Oliveira, W.E.; Franca, A.S.; Oliveira, L.S.; Rocha, S.D. J. Hazard. Mater. 2007, 152, 1073. 
6. Benhima, H.; Chiban, M.; Sinan, F.; Seta, P.; Persin, M. Colloids Surf. B: Biointerf. 2008, $61,10$.

7. Katicioglu, H.; Aslim, B.; Turker, A. R.; Atici, T.; Beyath, Y. Biores. Technol. 2008, 99, 4185.

8. Pehlivan, E.; Yanik, B.H.; Ahmetli, G.; Pehlivan, M. Biores. Technol. 2008, 99, 3520.

9. Ghodbane, I.; Nouri, L.; Hamdaoui, Q.; Chiha, M. J. Harzard. Mater. 2008, 152, 148.

10. Ruiz, C.G.; Tirado, V.R.; Gil, B.G. Biores. Technol. 2008, 99, 3864.

11. Panda, G.C.; Das, S.K.; Guha, A.K. Colloid. Surf. B: Biointerf. 2008, 62, 173.

12. Muramoto, S.; Oki, Y. Bull. Environm. Contam. Toxicol. 1983, 30, 170.

13. Shao-Wee, L; Chang, Wen-Lian, C. J. Aquat. Plant Manage. 2004, 42, 60.

14. Yang, J.B.; Volesky, B. Environ. Sci. Technol. 1999, 33, 75.

15. Low, K.S.; Lee, C.K. Pertamka J. Sci. Technol. 1997, 5, 147.

16. Mckay, G. Water Resour. 1982, 32, 759.

17. Puranik, P.R.; Paknikar, K.M. J. Biotechnol. 1997, 55, 113.

18. Davila-Jimenez, M.M.; Elizalde-Gonzalez, M.P.; Geyer, W.; Mattusch, J.; Winnerich, R. Colloid. Surf. A: Physicochem. Eng. Aspect. 2003, 219, 243.

19 Fourest, F.; Roux, J. Appl. Microbial. Biotechnol. 1992, 37, 399.

20. Lodeiro, P.; Barriada, J.L.; Herrero, R.; Sastre de Vicente, M.E. Environ. Pollut. 2006, 142, 264.

21. Tokimoto, T.; Kawasaki, N.; Nakamura, T.; Akatugawa, J.; Tanada, S. J. Colloid. Interf. Sci. 2005, 281, 56 .

22. Salim, R.; Al-Subu, M.; Qashow, S. J. Environ. Sci. 1994, 29, 2087.

23. Davis, T.A.; Volesky, B.; Mucci, A. Water Res. 2003, 37, 4311.

24. Herrero. R.; Lodeiro, P.; Rojo, R.; Ciorba, A.; Rodriguez, P.; Sastre de Vicente, M.E. Biores. Technol. 2008, 99, 4138.

25. Matheickal, J.T.; Yu. Q. Water Sci. 1996, 34, 10.

26. Baig, J.H.; Garcia. A.E.; Tiemann. K.J.; Garedea-Torresday, J.L. Proceedings of the 1999 Conference on Hazardous Waste Research 1999 [Online [last visited on $1^{\text {st }}$ August 2008 p. 131-142; Available at: hppt://www.engg.ksu.edu

27. Gupta, R.; Ahuja, P.; Khan, S.; Saxena, K.R.; Mahopatra, H. Curr. Sci. 2000, 78, 96.

28. Cutsem, P.V.; Metdagh, M.M.; Rouxhet, P.G., Gillet, C. Polm. 1984, $2,31$.

29. Al-Asheh, S.; Banat, F.; Mohai, F. Chemosphere 1997, 39, 2087.

30. Brown, P.A.; Brown, J.M.; Allen, S.J. Biores. Technol. 2001, 78, 195.

31. Abdel-Halim, S.H.; Shehata, A.M.A.; EI-Shahat, M.F. Water Res. 2003, 37, 1678.

32. Al-Subu, M.M. Environ. Resour. 2002, 6, 569.

33. Salim, R.; Al-Subu. M.; Qashow, S. J. Environ. Sci. 1994, 29, 2087.

34. El-Ashtoukhy, E.-S.Z.; Amin, N.K.; Abdelwahab, O. Desalination 2008, 223, 162.

35. Ho, Y.-S. Polish J. Environ. Stud. 2006, 15, 81.

36. Mbadcam, J.K.; Anagho, S.G.; Nsami, J.N.; Kammegne, A.M. J. Environ. Chem. Ecotoxicol. 2011, 11, 290.

37. Loukidou, M.; Zouboulis, A.; Karapantsios, T.; Matis, K. Colloid. Surf. A: Physicochem. Approach. Eng. Aspect. 2004, 242, 93. 